\title{
THE BRIEF OVERVIEW OF THE ANALYSIS OF POLITICAL LANGUAGE IN THE CZECH-POLISH CONTEXT WITH REFERENCE TO THE ELECTION SPOTS IN THE EUROPEAN PARLIAMENT IN 2009
}

\author{
Janusz Karpeta ${ }^{1}$ \\ ${ }^{1}$ Silesian University in Opava, School of Business Administration in Karviná, Univerzitní nám. 1934/3, 73340 \\ Karviná \\ Email:karpeta@opf.slu.cz
}

\begin{abstract}
The article deals in three parts with individual issues of the approaches to the analysis of political language largely in the Polish and partly Czech cultural-linguistic environment in the context of the election to the EP in 2009. The first part deals with rhetoric and political language, the second part focuses on political language and propaganda and finally it concludes with political language and manipulation. The article proceeds from the latest findings and studies and analyses political language in the broader context of the election spots to the EP 2009 with an emphasis on selected areas in rhetoric, propaganda and manipulation. Then, an analogy is found along with the connection of scientific research with the language used in the election spots to the EP the 2009.
\end{abstract}

Keywords: election spot, language, manipulation, propaganda, rhetoric.

JEL classification: Z00

Doručeno redakci: 18.8.2011; Recenzováno: 21.1.2013;10.4.2013;20.5.2013; Schváleno k publikování: 11.9.2013

\section{Introduction}

The following paper will outline the main reference areas of modern election spots in the European Parliament in the Czech Republic and Poland in the context of the historical development of communication based on the latest findings. The main objective is to demonstrate then the existing incorporation of various communication techniques in the contemporary language of election spots in the European Parliament. The outcome is to prove the existence of communication techniques in the modern political language during the election period in the European Parliament.

\section{Rhetoric and political language}

At the beginning of this paper it is generally assumed that the roots, communication techniques and their reflection in political communication in modern election spots these days can be undoubtedly found in one of the oldest scientific disciplines, which is the rhetoric. Yet, the first tangible body of evidence of all of those communication techniques in the European and Christian context can also be found in the language of the Gospel of John, where the original meanings of the words and its implications can be seen: "In the beginning was the Word, and the Word was with God, and the Word was God. "1. They both constitute the basis for various communication techniques and styles as well as for public speaking in the subsequent centuries. Obviously their development in further communication stages has gone through many changes over the centuries and they had to be adapted to new conditions and needs of social, political or cultural spheres. Election spots to the European Parliament in 2009 , as well as the methodology of the study of political discourse, as I will show in the following section, therefore fill the basic premises of the oldest scientific disciplines, and refer to the old tradition of classical rhetoric.

\footnotetext{
${ }^{1}$ The Gospel according to John King James, translation 1611
} 
I will commence with the definition of rhetoric that can be found in the professional literature: "...the term rhetoric comes from the Greek language and it has been known for more than two thousand years and is an efficient and functional art of persuasion in speech and writing. What is important for our considerations is the legal-judicial rhetoric pedigree. Every free Greek citizen had to assert his rights himself, defend himself or accuse before Aeropag. The ability to speak beautifully along with the power of persuasion had a decisive influence on the decision taken by the council of elders." ${ }^{2}$ Using a similar analogy - i.e. the one that emphasizes the art of "beautiful" speaking in public, one can state that the language used in spots to the EP election in 2009 aims in a similar way to persuade voters to cast votes to a particular political grouping or to attract new voters and, therefore, urge to act and take an active part in the elections by visiting the ballot box. For that purpose politicians and political parties use in their language such words, which should support their beliefs and political opinions influencing thus the voters. Among those can be ranked various verb, adjective and noun forms, which subconsciously affect the minds of the voters and make them believe in those words presented in the election spots.

Let us now return briefly to the development of rhetoric, in the words of Miroslaw Korolki "...rhetoric from the beginning was an open and evolving system. Attempts to codify the rules had been made by Aristotle, Cicero and Quintilian. Rhetoric became very early part of the basic school subjects in the trivium, besides grammar and dialectics. In modern education, it appeared under the name eloquentia or ars oratoria, in Poland and in the rhetoric of school curricula it also appeared as "pronunciation and poetry." However, the increasing use of the beautiful art of speaking and writing to a panegyric oratory influenced the spread of the opinion that this is the art of bafflement and double talk, and not how Quintilian wanted it to be as "the most precious gift that the gods left the mortals." ${ }^{3}$ In the Czech Republic, we can find a similar place of rhetoric in the school curricula.

Continuing the successive stages of the development rhetoric, A. Siewerska Chmaj notes: "After years of oblivion, initiated during the Enlightenment cult of pure reason, rhetoric survived the momentary revival at the turn of the century of $19^{\text {th }}$ and $20^{\text {th }}$ centuries, when it was brought back particularly hard in 1936, when Ivor Armstrong Richards' book, The Philosophy of Rhetoric appeared. It was a statement of the new school New Rhetoric, whose essence was the use of rhetoric to the theory of mass communication and the use of its rules in the techniques of propaganda and advertising. Since then, the rhetoric has been adopted by the modern theory of communication and is of interest to linguists, philosophers, psychologists, sociologists, but also specialists in advertising, public relations and political marketing. "

At this point it is worth noting that the rhetorician need was quickly recognized in the modern business world, politics and culture A. Siewierska Chmaj confirms these words: "modern man who is not even familiar with the concept of rhetoric or who uses it as a synonym for empty words, uses its achievements, to express thoughts in an efficient, purposeful and functional way. Rhetoric has become an integral part of advertising, media, language, and above all political language" 5 .

\footnotetext{
${ }^{2}$ SIEWIERSKA-CHMAJ, A., 2006. Jezzyk polskiej polityki. Politologiczno-semantyczna analiza expose premierów Polski w latach 2001-2004, Rzeszów

${ }^{3}$ KOROLKO, M., 1990. Sztuka retoryki, Warszawa, p. 21;

${ }^{4}$ SIEWIERSKA-CHMAJ, A., 2006. Język polskiej polityki. Politologiczno-semantyczna analiza expose premierów Polski w latach 2001-2004, Rzeszów.

${ }^{5}$ SIEWIERSKA-CHMAJ, A., 2006. Język polskiej polityki. Politologiczno-semantyczna analiza expose premierów Polski w latach 2001-2004, Rzeszów.
} 
However, these days, in times of globalism, one can find another application and i.e. the one in public disciplines, such as public speaking, public relations, marketing and advertising. The demands of the market create the needs to adapt also the contents of modern rhetoric to the needs of enterprises and markets. Both of them understand the significance of the power of words and speaking, as more and more schools and universities offer tailored made rhetoric courses.

In the Polish professional literature Walery Pisarek puts together a "list of concepts contained in the contemporary rhetoric of the semantic field ${ }^{6 / *}$ :

- Persuasion, persuasion, argumentation, negotiation, eristic;

- Propaganda, agitation, demagogy, manipulation, indoctrination, brainwashing, disinformation;

- Promotion, advertising, marketing, public relations, acquisition, copywriting;

- Promoting, popularizing, disseminating;

- Upbringing, education, learning, formation, social engineering;

- Eloquence, speaking, speech, discourse, oratory;

- Preaching, homiletics, catechesis, preaching, eclecticism;

- Pragmatics, pragma-linguistic, grammar text, linguistic texttology;

- Stylistics, topika (loci communes), metaphoric, poetics ${ }^{7}$.

All of the above concepts also reflect the language demands of political communication in the election spots for the EP 2009. On different levels of the political language, i.e. on the morphological, lexical and syntactical levels, we can observe, as in the dialogues between a political party and voters, the means of persuasion, manipulation, agitation, advertising, and marketing are frequently applied. The result of these measures is to persuade voters to vote and to support a particular political party. These words are evidenced by another author: "rhetoric is a way to influence the audience by means of discourse which does constitute neither evidence nor an act of violence. It makes what is likely and more attractive" $" 8$.

\section{Political language and propaganda}

Propaganda, which was mentioned by Walery Pisarek in the context of the semantic field of rhetoric, appears frequently in the literature on political communication and can be studied within political discourse within the elections to the EP 2009.

Let us now draw attention to the meaning of propaganda. According to the Popular Encyclopedia PWN: "...this is a deliberate impact on the collective and individual efforts heading for- through the use of intellectual and emotional persuasion - to educate desired beliefs and behaviors." ".

"A Psychological Definition of Propaganda" by W.Bidell from 1931 is considered to mark the beginning of the theory of propaganda as a field of science. W. Bidell provides the following definition: "Propaganda affects every individual in such a way that he behaves as if his reactions were a result of its own decisions. Many units can be forced to the same behavior,

\footnotetext{
${ }^{6}$ SIEWIERSKA-CHMAJ, A., 2006. Język polskiej polityki. Politologiczno-semantyczna analiza expose premierów Polski w latach 2001-2004, Rzeszów.

${ }^{7}$ PISAREK, W., 1999. Retoryki dziś w Polsce w: „Zeszyty prasoznawcze” nr 3-4, Kraków, p. 116;

${ }^{8}$ RICOEUR, P., 1989,. Język, tekst, interpretacja:wybór pism..., Warszawa, Państwowe Wydawnictwo

Naukowe, p. 127.

${ }^{9}$ Encyklopedia popularna, Warszawa 1999.
} 
while each is seemingly guided by his own judgments." ${ }^{10}$ Further the professional literature cites more definitions that were later developed by subsequent researchers. At this point it is worth quoting the definition by D. Krech, R. Crutchfield (psychological perspective): "...propaganda is understood as a specific form of beats, which - if effective - results in a process of suggestion"",11 L. Fraser, who analyzes the propaganda from the standpoint of political science, understand the propaganda in the following way, "Propaganda can be defined as the art of forcing people to do what they would not do if they had all corresponding data on the situation. ${ }^{12}$." G.S. Jowett, V. O'Donnell (political science approach) cites another definition: "Propaganda is the deliberate and systematic attempt to shape perceptions, manipulate the thoughts and direct behavior to achieve such reactions, which are consistent with the desired intentions of the propagandist"13. Jacques Ellul (sociological approach) states: "The set of the methods used by organized groups for the purpose of active mass audience's performance, who, in consequence of the psychological manipulation, create the psychological unity, which allows for their inclusion in the mass action"14. At the end I am presenting the last characteristic of propaganda by T. Parsons (sociological approach): propaganda is "an attempt to influence the attitudes and thereby directly or indirectly to the actions of people using the stimuli of the language of the written or spoken word"

As it follows from the above specifications of propaganda, the stated approach shows a high degree of interdisciplinary in the field of propaganda research, yet one can also track down the following aspects contained in the definitions of propaganda, namely the "appropriateness, organized nature, using appropriate methods, the impact on the attitudes and actions, and mediation media" "16. Almost all attributes appear frequently in the analysis process of political communication and political language alone. As A. Siewierska-Chmaj noted: "A major contribution to the study of this phenomenon were also Polish linguists, who identified such five basic functions of propaganda" ${ }^{17}$.

"The first is the integration feature, aimed at stabilizing the existing socio-political system through the unification and strengthening of the functioning of structures, mainly addressed to educated people, who have access to information.

The second function is referred to as adaptive or agitation - its task is to urge people for action, education of the desired patterns of behavior and to gain acceptance for the ideology, power or political system. Information and interpretative function consists of two parts information and interpretation, the second member plays a crucial role. Another feature, disinformation is used most often in external propaganda, against political opponents and enemies of the state. The unmask function can be met in the case of denying incorrect information" $" 18$.

\footnotetext{
${ }^{10}$ KRECH, D., R. CRUTCHFIELD, 1948. Theory and Problem of Social Psychology, New York, p. 316.

${ }^{11}$ D. KRECH, D., R. CRUTCHFIELD, 1948. Theory and Problems of Social Psychology, New York; L. Fraser, Propaganda, London 1957; G.S. Jowett, V. O’Donnell, Propaganda and Persuasion, Beverly Hills 1986, p.366.

${ }^{12}$ DOBEK-OSTROWSKA B., J. FRAS, B. OCIEPKA, Teoria i praktyka propagandy, op.cit., p. 9.

${ }^{13}$ JOWETT G.S., O’DONNELL V., 1986. Propaganda and Persuasion, Sage Publications, Beverly Hills, p. 16

${ }^{14}$ ELLUL J., Propaganda, Vintage Books, New York 1965, p. 9

${ }^{15}$ PARSONS T., 1972. Propaganda i kontrola spoteczna $\mathrm{w}$ „,Szkice z teorii socjologicznej”, Warszawa p. $179-230$

${ }^{16}$ DZIOMDZIORA, K., 2008. Teoria i praktyka propagandy na przyktadzie Radia Maryja, Warszawa

${ }^{17}$ SIEWIERSKA-CHMAJ, A., 2006. Język polskiej polityki. Politologiczno-semantyczna analiza expose premierów Polski w latach 2001-2004, Rzeszów

${ }^{18}$ B. DOBEK-OSTROWSKA, J. FRAS, B. OCIEPKA, 1997. Teoria i praktyka propagandy. Wrocław, pp. 2930 ;
} 
Although at the present time the political parties do care about a positive image and do not like to be seen as a political party based on propaganda, nevertheless, one can consider the process of communication in spots to the EP election in 2009 from the viewpoint of the use of alternating second, third and fourth functions. At the same time almost all political parties want to ensure that the system of the presented functions would preferably affect the recipient, i.e. the voter and would not cause adverse effects.

Within the framework of political communication it is worth paying attention to another important aspect, which concerns the perception of the language of propaganda and political language. A.Siewierska-Chmaj ${ }^{19}$ notices in this place an important differentiation: "...an integral relationship between the communist propaganda and its tool newspeak that influenced the identification for many years, in the social acceptance of newspeak with political language. The main difference between the political language and the language of propaganda relates to the process of linguistic communication, which until 1989 was mainly one-sided. The sender directed texts to the recipient, who could not respond to them unless they spoke the same voice as the sender",20.

Next A. Siewierska-Chmaj notes: "...newspeak was characterized by unanimity, the right to speak in public about political and social issues belonged to the representatives of authority. One of the main features of the then communication model with the public was the stability of the language, which, moreover, was to be coherent with the stability of the system - what could better create a coherent picture of reality than internally consistent way to communicate" ${ }^{21}$.

Another prominent researcher in the field of political communication professor Jerzy Bralczyk characterized propaganda in the following way: "...public written, political, ideological, propaganda texts were formulated in an increasingly specified, an established language. In the language, where the primacy of the coherent concept of truth was noticeably over the one of correspondence. We encountered public statements, where there was loyalty to the lexicon and phraseology, which were subordinated to the syntax. More important was the use of the ideological and political stabilized set of words rather than adding contents to the sentences. There was ritualization of a public message, the situation, and by accepting the status quo the subordination of all the strict norms of public speaking could be induced. However, there was also the alienation of such a language - recognized as negatively marked, because it was not congruent with reality, escapist..."22

In the next stage of the development of political language within political communication occurs, as A. Siewierska-Chmaj observes:"...discredit of the propaganda language characteristic of the one-party system on the one hand, and new communication needs on the other one, which thus became the basis for the emergence of a new variety of Polish language, a new type of texts, which did not already fall within the concept of the language of propaganda, and rhetoric of power " 23 . Thus there is a significant change in political

\footnotetext{
${ }^{19}$ SIEWIERSKA-CHMAJ, A., 2006. Język polskiej polityki. Politologiczno-semantyczna analiza expose premierów Polski w latach 2001-2004, Rzeszów.

${ }^{20}$ M. FRANKOWSKA, 1994. Frazeologia i metaforyka w tekstach politycznych lat 1989 - 1993, w: Język a kultura, t. 11: Język polityki i współczesna kultura polityczna, Wrocław, p. 21;

${ }^{21}$ SIEWIERSKA-CHMAJ, A., 2006. Język polskiej polityki. Politologiczno-semantyczna analiza expose premierów Polski w latach 2001-2004, Rzeszów.

${ }^{22}$ BRALCZYK, J., 2003. O języku polskiej polityki lat osiemdziesiatych i dziewięćdziesiatych, Warszawa, p. 38;

23 SIEWIERSKA-CHMAJ, A., 2006. Język polskiej polityki. Politologiczno-semantyczna analiza expose premierów Polski w latach 2001-2004, Rzeszów.
} 
communication and is primarily in a mutual flow of information, and therefore the two-way communication takes place, as we know in times of democracy and pluralism. Related trends in the development can be found in the Czech political environment. In accordance with J.Kraus: ,....into the public political discourse in the years of totalitarian regime marked by one-sided opinions and monologue, the spirit of dialogic thinking and polemical excesses began consistently to penetrate. Its language was naturally marked by the expression of many attributes of the immediate spoken expression..." 24

As it has been demonstrated, the political language used in the election to the EP has given way to a dialogue between the political parties and voters, enabling thus the free flow of information and its dissemination to the public. Any hints of propaganda were carefully avoided by the political parties, yet some of them, at least in the Czech Republic, opted for using a stronger political discourse (Moravané, BPS, KČ and DS), which could be partly linked with the language of propaganda. It was not the case in Poland.

\section{Political language and manipulation}

Within professional studies in the field of political communication one may come across another element in political language and i.e. manipulation. Manipulation should be also studied in the context of Postmodernity, whose sociological paradigms constitute the basis for modern manipulation and manipulation techniques. Magdalena Trysińska narrows manipulation as follows: "Political manipulation is a set of propaganda activities, organizational, diplomatic, procedural and electoral, ritual and others intended to elicit specific social and individual behavior and shape opinions, which make it easier to subjects of manipulation achieve the objectives hidden from the public, including especially people who are the subject of manipulation ... while I understand the manipulation of language as a way to influence by means of language attitudes of recipients. In a broader sense it is carried out through the manipulation of texts. Its sphere also includes a lie and all demagogy and manipulation stereotypes. In a narrower sense, we are dealing here with manipulation, in which linguistic resources, that is certain features of words and grammatical structures (not the content itself expressed by them) allow to influence the recipient, who does not realize it at all. ${ }^{25}$ " As derived from the above definition, and also with previous observations on the analysis of political communication and election campaigns, which take in count the rhetoric, propaganda, manipulation, aspects of manipulation penetrate also into the style of the EP election campaign in 2009 and appear in it, although the political parties themselves do not like be connected with the "pejorative" expression which the word manipulation alone is. Returning to the definition given above, we are therefore able to see a similar analogy in the EP election campaign in 2009, which applies Magdalena Trysińska. The first level, where you can see the manipulative treatments, and where manipulation appears, is presented by the public communication of political groups. As it is well known, political groups cooperate with experts in the field of public communication, marketing or PR, and use almost all available means of modern electoral rhetoric and public communication. In the case of the EP election campaign in 2009 one of the most effective means or a tool that political parties often use on a mass scale are audio-visual media - i.e. election spots. The presented here tools are intended to maximally have an impact on the voters and convince them to the desired action - i.e. going to the polls and casting a ballot for the specific political party concerned.

The second level is constituted by morphological means of language along with studying the levels of grammar, lexicology and syntax also in terms of linguistic manipulation.

\footnotetext{
${ }^{24}$ KRAUS, J., S. ČMEJRKOVÁ and J. HOFFMANNOVÁ, 2003. Jazyk, média, politika, Academia, Praha. p.13

${ }^{25}$ TRYSIŃSKA, M., w P. KRZYŻANOWSKI and P. NOWAK, 2004. Manipulacja w języku, Lublin. p.222
} 
In the present context we should also note how it comes to the implementation of manipulative activities during the campaign election and who the subjects of manipulation are. The professional literature cites the model of manipulation, which was taken up by Małgorzata Kita: "... who - manipulates - with whom - by means of what / how?" ${ }^{26}$ Let us commence with the first element occurring in the model of manipulation - who. In this role, of course, there are politicians or political groups. They manipulate with whom - that is, voters, using both verbal and nonverbal available linguistic resources (individual verbal language tools are the subject of analysis given in the next chapters of my work) in the message in the of an election spot. However, at the same time the objects of manipulation are also politicians themselves. The model of manipulation in the election campaign for 2009 in the EP election spots of the political spectrum refers, extends simultaneously and substantially modifies the rules Aristotelian rhetoric and its scope, thus creating a specific communication model based on the rhetoric of audio-visual, applied to the strengthening of manipulation based on the principle "one keeps talking .."",27. The rhetoric of audio-visual shows an effective, modern instrument of manipulation. What is therefore audio-visual rhetoric and what means does it use to manipulate? As Małgorzata Kita puts it:"...classical orator stood face to face with his audience, to whom he addressed, to whom he spoke, the today's orator - is facing an impersonal camera, which transfers his image to the audience, so there is no direct contact between the sender and recipient. Even the presence of a journalist in the studio or the audience does not change this fact, - the speaker is directed by the telegenic communication behavior imperative, in order to establish a favorable image in the media and for politicians the image on the screen is crucial that the image on the screen, not a direct response to recipients, although he does not ignore them...,"28

Similar conclusions derive from the activities of political groups in the EP elections in 2009. Almost all of them that use television cameras to create a perfect image, while in the field of the language they use the available means to manipulate, such as: the use of verbs in the imperative and the conditional, the use of direct discourse to the recipient, the use of strongly marked by emotional words, repetition of the same words or their synonyms, hyperbolas, figures of speech, etc. ${ }^{29}$ The instruments of manipulation should thus strengthen and arouse emotions and evoke positive feelings with voters, and convince him of the virtue of the given political party as for the platform and to gain his approval and most importantly, support in the EP elections of 2009.

\section{Conclusion}

As it has been demonstrated and subsequently proved in the above paragraphs, one can find logical and clear analogies of individual elements of rhetoric, propaganda and manipulation techniques in the given election spots to the EP 2009. What should be also stressed is the common interdisciplinary feature of all of them. Both the Czech and Polish election environments have gone through similar developmental stages, as far as the development of political language is concerned both from the economic and mainly political perspectives. At the same time, both election environments are dominated by strong international and global trends in public communication followed by 1989, such as modern telecommunication and audio visual techniques, which dominate the communication market these days. Yet all modern political parties avoid carefully direct means of propaganda and manipulation and rather develop more sophisticated models of political communication, in which the latest

\footnotetext{
${ }^{26}$ KITA, M., w P. KRZYŻANOWSKI, P. NOWAK, 2004. Manipulacja $w$ języku, Lublin. p.203

${ }^{27}$ TRYSIŃSKA, M., w P. KRZYŻANOWSKI, P. NOWAK, 2004. Manipulacja $w$ języku, Lublin. p.206

${ }^{28}$ TRYSIŃSKA, M., w P. KRZYŻANOWSKI, P. NOWAK, 2004. Manipulacja w języku, Lublin. p.205

${ }^{29}$ See SZAGAŁA, I., 2008- Językowe środki manipulacji i perswazji w reklamie. Warszawa.
} 
pieces of knowledge in the field of public communication and marketing communication are extensively applied, as the latest trends in the studies by e.g. Jerzy Bralczyk and Andrzej W. Jablonski show. The emphasis is rather put on the marketed product, which is in our context the political language of the election spots, which has to fulfill the similar criteria for a successful product, as it is the case in marketing, where it has follow the four Ps and AIDA principles.

\section{References}

[1] BRALCZYK, J., 2003. O języku polskiej polityki lat osiemdziesiatych $i$ dziewięćdziesiatych, Warszawa.

[2] DOBEK-OSTROWSKA, B., J. FRAS and B. OCIEPKA, 1997. Teoria i praktyka propagandy. Wrocław.

[3] DZIOMDZIORA, K., 2008. Teoria i praktyka propagandy na przyktadzie Radia Maryja, Warszawa.

[4] ELLUL J., 1965. Propaganda, Vintage Books, New York.

[5] Encyklopedia Popularna PWN, 1991. Warszawa, PWN.

[6] FRANKOWSKA, M., 1994. Frazeologia i metaforyka $w$ tekstach politycznych lat 1989 - 1993, w: Język a kultura, t. 11: Język polityki i współczesna kultura polityczna, Wrocław.

[7] JOWETT, G. S. and V. O’DONNELL, 1986. Propaganda and Persuasion, Sage Publications, Beverly Hills.

[8] KITA, M., P. KRZYŻANOWSKI and J. NOWAK, 2004. Manipulacja $w$ języku, Lublin

[9] KOROLKO, M., 1990. Sztuka retoryki, Warszawa,

[10] KRAUS, J., S. ČMEJRKOVÁ a J. HOFFMANNOVÁ, 2003. Jazyk, média, politika, Academia, Praha

[11] KRECH, D. and R. CRUTCHFIELD, Theory and Problems of Social Psychology, New York 1948; Fraser, L., Propaganda, London 1957; Jowett, G.S., O’Donnell, V., Propaganda and Persuasion, Beverly Hills 1986.

[12] PARSONS, T., 1972. Propaganda $i$ kontrola spoteczna w „Szkice $\mathrm{z}$ teorii socjologicznej", Warszawa

[13] PISAREK, W., 1999. Retoryki dziś w Polsce w: „Zeszyty prasoznawcze” nr 3-4, Kraków

[14] RICOEUR, P., 1989. Język, tekst, interpretacja:wybór pism..., Warszawa, Państwowe Wydawnictwo Naukowe,

[15] SIEWIERSKA-CHMAJ, A., 2006. Język polskiej polityki. Politologiczno-semantyczna analiza expose premierów Polski w latach 2001-2004, Rzeszów

[16] SZAGAŁA, I., Językowe środki manipulacji i perswazji w reklamie. Pedagogiczna Biblioteka Wojewódzka im. KEN w Warszawie 2008.

[17] TRYSIŃSKA, M, P. KRZYŻANOWSKI and P. NOWAK, 2004. Manipulacja w języku, Lublin 